\title{
ハイブリッド型磁気軸受を用いた磁気浮上型血液ポンプの開発 \\ Magnetically suspended blood pump with hybrid magnetic bearing
}

\section{○鈴木健 ${ }^{1}{ }^{1}$ ，增澤徹 ${ }^{2}$ \\ 1. 茨城大学大学院理工学研究科機械工学専攻，2. 茨城大学工学部機械工学領域 OKenichi Suzuki ${ }^{1}$ and Toru Masuzawa ${ }^{2}$}

1. Graduate school of Sci. and Eng., Ibaraki University,

\section{1.はじめに}

一般的に軸受にはボールベアリングなどが用いられているが， これらの軸受は磨耗したベアリングやオイルの交換といった定期 的なメンテナンスが必要である.一方, 磁気軸受は非接触, 長寿 命, メンテナンスフリーなどの特長を持ち, 異物の混入を嫌うケミ カルポンプや高耐久かつ長寿命が求められる人工心臟などへの 応用が期待されている. 中でも，ハイブリッド型磁気軸受は永久 磁石と電磁石の併用により, 小型化, 省エネ化が可能で現在注 目されている. 本研究では, 体外設置型血液ポンプや補助人工 心臓一の応用を目的としたハイブリッド型磁気軸受の開発, 小径 の磁気浮上型遠心ポンプの構築を行った.

\section{2. ハイブリッド型磁整受の概要}

本磁気軸受は，分割ステータコアと永久磁石およびロータ で構成された径方向支持のハイブリッド型磁気軸受である. ステータコアの各突極にはコイルが巻かれ，制御磁束を発生 させる電磁石となっている，氷久磁石は磁気軸受内に対向し た形で 2 個組み込まれ，磁気回路を径方向に二次元平面上に 形成する棈造となっている．Fig. 1 に本軸受の構造とロータ の浮上制御方法を示す，永久磁石が発生するバイアス磁束が 図の破線矢印方向に流れている。電磁石による磁束を実線矢 印方向に流寸ことで, 突極とロー夕間に流れる磁束を制御し, 吸引力を発生させる。この吸引力により、ロータの径方向位 置制御を行う。本磁気軸受の寸法は, 外径 $60 \mathrm{~mm}$, 口ー夕径 30 $\mathrm{mm}$ ，厚み $10 \mathrm{~mm}$, エアギャップ長 $1 \mathrm{~mm}$ である、コイル巻き 数は, $X$ 軸方向の 2 突極に 200 巻き, $\mathrm{Y}$ 軸方向の突極に 200 巻 きである。

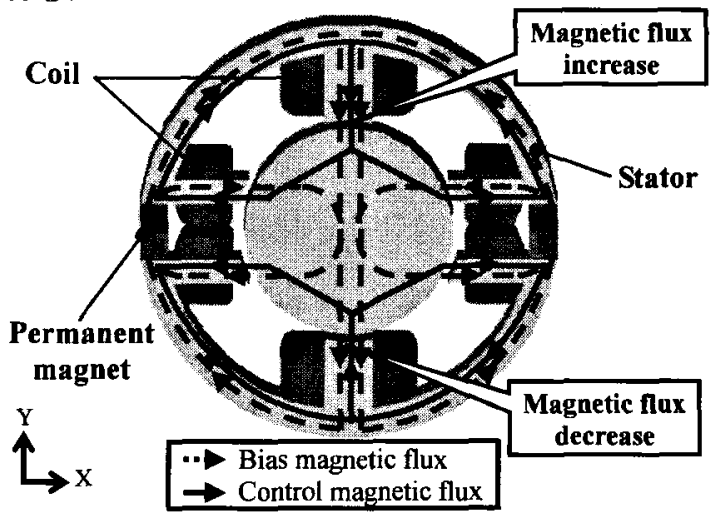

Fig. 1 Principle of force production of the magnetic bearing 3. 磁気浮上型遠心ポンプの概要

製作したハイブリッド型磁気軸受を用いて遠心ポンプを構築し， ポンプ拍出性能評価およびポンプ動作中のロータインペラの径 方向振動掁幅を測定した. 本ポンプは，2つの磁気軸受とモー夕 でロータインペラの浮上・回転を行う.浮上制御は, DSP を用い て, 4 個の渦電流センサによりロータインペラの径方向位置を検 出し, デジタル PID 制御を行う.

\section{4. 結果と考察}

Fig. 2 に構築した磁気浮上型遠心ポンプを, Fig. 3 に開発し た磁気浮上型遠心ポンプのポンプ拍出性能を示す. 本ポンプは 水中で $4500 \mathrm{rpm}$ まで浮上回転が可能で, 最大揚程は 188 $\mathrm{mmHg}$, 最大流量は $14 \mathrm{~L} / \mathrm{min}$ であり, 血液ポンプとして優れ
2. Dept. of Mechanical Engineering, lbaraki University

た性能を有していることを確認した。 また, 浮上回転しているロい タインペラの最大振動振幅は $0.06 \mathrm{~mm}$ であり, 流路幅 0.5 $\mathrm{mm}$ より十分に小さく, 安定した浮上回転が可能であることを確

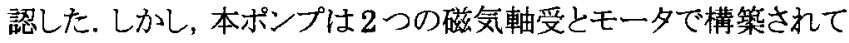
おり，サイズが大きく，人工心臟には不向きである. そこで，磁気 軸受のひとつをモータと一体化し，浮上・回転を行うセルフベアリ ングモータとすることで, ポンプサイズの縮小を図る. Fig. 4 に考 案した本磁気軸受とセルフベアリングモータを併用したポンプの 楧造図を示す. セルフベアリングモータを用いることで, ポンプの 軸方向長さを $30 \%$ 程縮小できる. 現在, 外径 $75 \mathrm{~mm}$, 厚さ 10.5 mm のセルフベアリングモータを開発し, 性能評価中である.

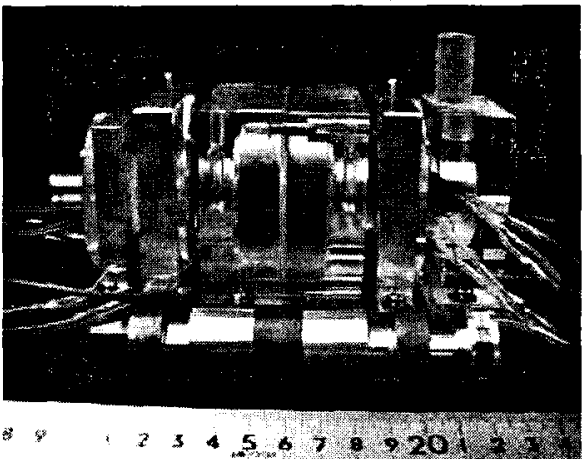

Fig. 2 Developed magnetically suspended pump

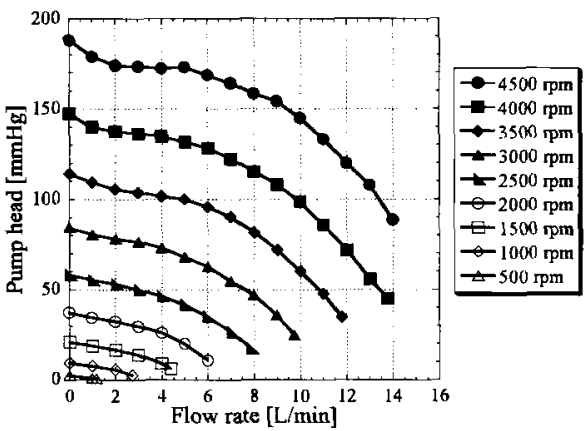

Fig. 3 Head pressure-flow rate characteristic

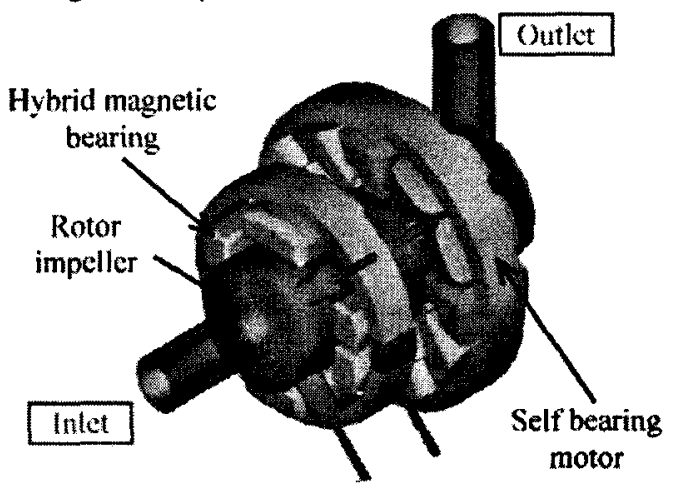

Fig. 4 Magnetically suspended pump with self bearing motor 5. まとめ

今回, ハイブリッド型磁気軸受を用いて磁気浮上型遠心ポンプ を構築し，その性能評価を行った. 本ポンプは, 血液ポンプとして 十分に実用可能な性能を有していることを確認した。 